\title{
Genetic studies of soybean [Glycine max (L.) Merr.] response to seed storage stress factors
}

\author{
Gbemisola OKUNLOLA ${ }^{1,2}$, Emmanuel IDEHEN ${ }^{1}$, Johnson ADETUMBI ${ }^{3}$, Christopher ALAKE ${ }^{1}$, \\ Solomon AKINYOSOYE ${ }^{3}$, Oluwafemi AMUSA ${ }^{4}$
}

Received June 03, 2019; accepted June 03, 2020.

Delo je prispelo 03. junij 2019; sprejeto 03. junij 2020

Genetic studies of soybean [Glycine max (L.) Merr.] response
to seed storage stress factors
Abstract: Soybean [Glycine max (L.) Merr.] responded differently to storage stress factors. This research work aimed at assessing genetic potentials of fifteen soybean varieties to storage stress via accelerated aging technique and grouping them based on their levels of tolerance to storage stress using simple sequence repeat (SSR). Tolerance of the seed of 15 soybean varieties to storage stress was assessed by subjecting them to accelerated aging for $0,6,12$, and 24 hours at $42{ }^{\circ} \mathrm{C}$ temperature and $100 \%$ relative humidity (RH), after which their quality was assessed to determine their tolerance to storage stress. Same varieties were also stored for 6 months under ambient environment at $65 \pm 5 \%$ R.H and $25 \pm 2{ }^{\circ} \mathrm{C}$ and they were genotyped with 19 simple sequence repeat (SSR) markers. The varieties were grouped on the basis of their levels of tolerance to storage stress. The principal components analysis (PCA) showed that germination rate index (GRI) and germination index (GI) were the major indices responsible for the significant variation in the seedling vigor characters. TGX1835-10E and TGX1448-2E were identified as varieties with good storage ability and therefore recommended for storage improvement in soybean breeding programs. Six SSR markers (Satt 565, Satt 175, Satt 281, Satt 600 , Satt 160 and Satt 281) were identified as candidate markers for detection of alleles for tolerance to storage stress.

Key words: soybean; seed accelerated aging; principal components analysis (PCA); dendrogram; SSR markers; tolerance
Genetske raziskave soje [Glycine max (L.) Merr.] v povezavi s stresnimi dejavniki pri shranjevanju semena

Izvleček: Genotipi soje (Glycine $\max$ (L.) Merill) se odzivajo različno na stresne dejavnike med shranjevanjem semena. Namen raziskave je bil oceniti genetski potencial 15 sort semen soje na stres med shranjevanjem pri pospešenih tehnikah staranja. Genotipi so bili razvrščeni na osnovi njihove tolerance na stres med staranjem na osnovi enostavnih ponavljajočih se zaporedij (SSR) in agronomskih lastnosti. Toleranca 15 sort semen soje na stres med shranjevanjem je bila ocenjena $\mathrm{z}$ izpostavitvijo pospešenemu staranju za $0,6,12$, in 24 ur pri $42{ }^{\circ} \mathrm{C}$ in $100 \%$ relativni vlažnosti (RH). Nekatere od sort so bile shranjene tudi za 6 mesecev v razmerah $65 \pm 5 \%$ relativne vlažnosti in pri $25 \pm 2{ }^{\circ} \mathrm{C}$. Ti genotipi so bili ovrednoteni z markerji na osnovi19 enostavnih ponavljajočih se zaporedij (SSR). Sorte so se združevale na osnovi njihove tolerance na stres med shranjevanjem. Analiza glavnih komponent je pokazala (PCA), da sta bila indeks hitrosti kalitve (GRI) in kalitveni indeks (GI) najpomembnejša pokazatelja značilne variabilnosti v lastnostih, ki označujejo vigor sejank. TGX1835-10E in TGX1448-2E sta bili prepoznani kot sorti z dobro sposobnostjo shranjevanja in sta priporočeni v žlahtniteljskih programih soje za izboljševanje shranjevanja semena. Šest SSR markerjev (Satt 565, Satt 175, Satt 281, Satt 600, Satt 160 and Satt 281)je bilo prepoznanih kot primernih za ugotavljanje alelov odgovornih za toleranco na stres med shranjevanjem.

Ključne besede: soja; pospešeno staranje semen; analiza glavnih komponent (PCA); dendrogram; SSR markerji; toleranca

\footnotetext{
1 Federal University of Agriculture, Crop Improvement and Seed Enterprise Development, Abeokuta, Nigeria

2 Corresponding author, e-mail: gbemisolaokunlola1@yahoo.com

3 Obafemi Awolowo University, Institute of Agricultural Research and Training, Ibadan, Nigeria

4 University of Lagos, Department of Cell Biology and Genetics, Nigeria
} 


\section{INTRODUCTION}

Soybean (Glycine max (L.) Merrill) is one of the oldest cultivated leguminous crops (Verma and Shoemaker, 1996). It is one of the most important economical legumes in the world, providing protein and oil to food and animal feed industries, as well as base ingredients for hundreds of chemical products (Hedley, 2001). It is grown for its beans, which have numerous uses (Camara, 2000). The beans can be processed into various meals, such as soy meat, cakes, baby foods, "tofu," and "dawadawa"- a local seasoning product for stews and soups (Abbey et al., 2001). The ability of the crop to increase dietary quality of resource-poor people all over the world (Hartman et al; 2011) has increased the demand for the beans with equivalent increase in its production. Provision of sufficient high-quality seed to farmers at an affordable price at the right time is a big challenge because the seeds deteriorate rapidly in quality during storage and therefore soybean farmers face inadequate supply of quality seed during the planting season (Dugjeet al., 2009). However, it has been reported that loss of germination potential of soybean seed is more acute in tropical and sub-tropical regions of the world when compared with temperate environments (Bhatia, 1996). This is because temperature, which is one of the major storage stress factor affects the storability of the seeds and also causes chemical changes, such as hydrolytic and oxidative rancidity (changes in oil quality) in the seeds, leading to reduced seed quality and subsequent loss of viability across time (Baskin and Delouche, 1973). This resulted into farmers planting available seed that often has low vigor, which in turn affects the yield (Nkang and Umoh, 1997). It has been proved that cultivars respond differently to environment situations due to their genetic variability (Flajšman et al., 2019; Badu-Apraku et al., 2017). Hence researchers have explored the use genetic variability among germplasms to solve genetic and agronomic problems.

Principal component analysis (PCA) and cluster analysis are methods of statistical grouping of germplasm, which provide information regarding the contributions of each character to total variation and group individuals based on the their genetic attributes respectively. These two techniques aid effective selection by plant breeders and or geneticists in crop improvement programs. In solving problem of soybean seed deterioration during storage, there is need to understand genetic traits responsible for tolerance to storage stress, hence this research work aimed at assessing genetic constituents of fifteen soybean varieties and their response to storage stress via accelerated aging technique with a view to grouping them based on their levels of tolerance to storage stress using Simple Sequence Repeat (SSR) prim-

Table 1: List of Fifteen varieties of soybean and their attributes

\begin{tabular}{|c|c|c|c|c|c|c|}
\hline Serial Number & Varietal Name & Source & Seed colour & Days to maturity & $\begin{array}{l}\text { Initial Germination } \\
\%\end{array}$ & $\begin{array}{l}\text { Maturity } \\
\text { group }\end{array}$ \\
\hline 1 & TGX1990-52F & IITA & Milky White & $95-102$ & 97 & I \\
\hline 2 & TGX1989-48FN & IITA & Milky White & $95-110$ & 81 & II \\
\hline 3 & TGX1989-49FN & IITA & Milky White & $95-110$ & 95 & II \\
\hline 4 & TGX1835-10E & IITA & Milky White & $81-95$ & 97 & 00 \\
\hline 5 & TGX1990-46F & IITA & Milky White & $95-102$ & 83 & I \\
\hline 6 & TGX1990-95F & IITA & Milky White & $95-110$ & 84 & II \\
\hline 7 & TGX1987-19F & IITA & Milky White & $95-110$ & 89 & II \\
\hline 8 & TGX1990-78F & IITA & Milky White & $95-105$ & 96 & II \\
\hline 9 & TGX1989-53FN & IITA & Milky White & $95-105$ & 95 & II \\
\hline 10 & TGX1989-75FN & IITA & Milky White & $95-105$ & 83 & II \\
\hline 11 & TGX1990-114FN & IITA & Milky White & $108-115$ & 88 & II \\
\hline 12 & TGX1990-110FN & IITA & Milky White & $108-115$ & 97 & II \\
\hline 13 & TGX1440-1E & IAR\&T & Creamy & $90-100$ & 89 & I \\
\hline 14 & TGX1448-2E & IAR\&T & Creamy & $108-115$ & 89 & II \\
\hline 15 & TGX1740-1E & IAR\&T & Creamy & $90-100$ & 79 & I \\
\hline
\end{tabular}

IITA: International Institute of Tropical Agriculture IAR\&T: Institute of agricultural Training and Research Maturity group classification was according to Yuesheng et al., 2006. 
ers and identifying markers associated with tolerance or susceptible alleles in these soybean genotypes.

\section{MATERIALS AND METHODS}

\subsection{EXPERIMENTAL MATERIAL AND SOURCES}

Fifteen (15) soybean varieties were collected from International Institute of Tropical Agriculture (IITA) and Institute of Agricultural Research and Training, Obafemi Awolowo University (I.A.R \& T), both in Ibadan, Nigeria (Table 1).

\subsection{EVALUATION OF SEEDLING VIGOR CHAR- ACTERISTICS}

These soybean varieties were subjected to various seed quality assessment to determine their initial quality attributes. The tests conducted are:

Germination test: Fifty seeds in three replicates of each variety were planted in seed bowls filled with adequately moistened river sand. Germinated seedlings were counted daily as from $3^{\text {rd }}$ to $6^{\text {th }}$ day after sowing. Percentage germination $(\mathrm{G} \%)$ was determined by finding the ratio of normal germinated seed at 6 days after sowing to total number of seeds planted according to the method suggested by ISTA (1996) using Equation 1 :

$$
\% G=\frac{\text { No of normal seedlings that germinated }}{\text { Total number of seeds planted }} \times 100
$$

\section{(Equation 1)}

Seedling vigor assessment: Seedling vigor of the germinated seeds was assessed using the seedling vigor parameters suggested by various past researchers using equations (2) - (5)

Coefficient of velocity of Germination (CVG): This is an estimate of the rapidity of germination of the seed lot and it was estimated according to the method described by Scott et al. (1884).

$$
C V G=\frac{\Sigma N i}{\Sigma N i T i} \times 100
$$

\section{(Equation 2)}

Where: $\mathrm{N}$ is the number of seeds germinated each day and $\mathrm{T}$ is the number of days corresponding to $\mathrm{N}$

Germination Index (GI): This is an index of the speed of germination. This was calculated based on method described by Akande et al. (2012).

$$
G I=\frac{\Sigma(\mathrm{Nx})(\mathrm{DAP})}{\text { Total number of normal seedlings that emerged on final day }}
$$

(Equation 3) where $\mathrm{Nx}$ is the number of normal seedlings that emerged on day $\mathrm{x}$ after seeding and DAP is days after planting

Germination Rate Index (GRI): This reflects the percentage of germination on each day of the germination period and was calculated according to the method of Olisa et al. (2010). Higher GRI values indicate higher and faster germination (Kedar, 2005).

$$
G R I=\frac{G 1}{x}+\frac{G 2}{x}+\frac{G 3}{x}+\cdots \frac{G x}{x}
$$

\section{(Equation 4)}

where, $G=$ germination on each day after seed placement $1,2, \mathrm{x}=$ corresponding day of germination.

Seedling vigor Index (SVI): Seedling length was measured from five randomly selected seedlings of each replicate from the soil level at 3 and 6 days after planting. The SVI was then calculated based on method of Adebisi et al. (2004).

$$
S V I=\frac{(\text { Germination } \% x \text { Seedling length })}{100}
$$

(Equation 5)

\subsection{ACCELERATED AGING PROCEDURE, GERMI- NATION AND VIGOR TEST}

Twenty five grams ( $25 \mathrm{~g}$ ) of seeds in three replicates of the 15 soybean varieties were artificially aged using plastic boxes $(11.0 \times 11.0 \times 3.5 \mathrm{~cm})$ at $100 \%$ relative humidity and $42{ }^{\circ} \mathrm{C}$ temperature for 6,12 and 24 hours (Jagadishet al., 2013). Germination and seedling vigor attributes of the seed lots were determined after each aging period and compared to initial seed quality. The difference between the two quality factors determines their tolerance ability.

\subsection{AMBIENT SEED STORAGE}

Fifty grams $(50 \mathrm{~g})$ of clean seed of each variety was packaged into paper envelopes and stored under ambient environment with average relative humidity (RH) of $65 \pm 5 \%$ and temperature of $25 \pm 2{ }^{\circ} \mathrm{C}$ in the laboratory of Grain Legumes Improvement Programme of IAR \& T Ibadan for six months (Demir et al., 2008). Each variety was replicated three times and the envelopes were arranged in Completely Randomized Design (CRD). Samples of the stored seed were evaluated after six months of storage using procedure described above.

The germination percentage after accelerated aging and six months ambient storage was deducted from 
initial germination percentage to estimate the resistance ability of each variety, which resulted to the percentage germination loss ( $\mathrm{G}$ loss).

\subsection{DNA EXTRACTION AND MOLECULAR ANALYSIS FOR STRESS TOLERANCE TRIAL}

\subsubsection{DNA extraction}

Five grams of leave samples were harvested from the plant of each variety sown in the green house at about two weeks after planting and stored in ice, kept at $-20^{\circ} \mathrm{C}$ and later transported to Plant Science Laboratory of National Institute of Science Laboratory Technology, (NISLT) Ibadan, Nigeria for DNA extraction. Genomic DNA was extracted using the ZR Plant/Seed DNA MiniPrep $^{\mathrm{TM}}$ kit. DNA quantity and quality was measured using Nanodrop $^{\otimes}$ (ND-1000 spectrophotometer) at A 260/ absorbance. The ratio of A260/280 absorbance and values obtained ranged between 1.80 and 2.0, indicates good quality DNAs.

\subsubsection{Polymerase Chain Reaction}

The SSR amplification was carried out with 20 Simple Sequence Repeat (SSR) primers in $11 \mu$ reaction mixture consisting of $2.0 \mu \mathrm{l}$ of template DNA, $1.0 \mu \mathrm{l}$ each of forward and reverse primers, $1.0 \mu l \mathrm{dNTP}$ mix, $6.0 \mu \mathrm{l}$ PCR assay buffer. The PCR reactions were performed in a thermo-cycler with initial denaturation at $94^{\circ} \mathrm{C}$ for five minutes followed by 35 cycles of denaturation at $94^{\circ} \mathrm{C}$ for one minute, annealing for 30 seconds at $47^{\circ} \mathrm{C}\left(56^{\circ} \mathrm{C}\right.$ for Satt 565 and extension for $30 \mathrm{~s}$ at $72{ }^{\circ} \mathrm{C}$ with a final extension for seven minutes. The amplified products were separated on $6.0 \%$ polyacrylamide gel. Gels were run for $3 \mathrm{~h}$ at $75 \mathrm{~V}$ in $1 \mathrm{X}$ TBE buffer. DNA fragments were visualized under UV light and photographed using gel documentation system. An identified band (allele) on gels was binary coded as 1 or 0 to indicate their presence or absence respectively in soybean for each SSR primer. The names and sequences of the SSR primers are presented in Table 2.

\subsection{DATA ANALYSIS}

Data obtained from accelerated aging and ambient stor-

Table 2: The sequence and annealing temperature of the soybean SSR primers

\begin{tabular}{|c|c|c|c|}
\hline \multirow[b]{2}{*}{ Name of primer } & \multicolumn{2}{|l|}{ Sequence } & \multirow[b]{2}{*}{ AT $\left({ }^{\circ} \mathrm{C}\right)$} \\
\hline & Forward & Reverse & \\
\hline Satt423 & TTC GCT TGG GTT CAG TTA CTT & GTT GGG GAA TTA AAA AAA TG & 47 \\
\hline Satt414 & GCG TAT TCC TAG TCA CAT GCT ATT TCA & GCG TCA TAA TAA TGC CTA GAA CAT AAA & 47 \\
\hline Satt434 & GCG TTC CGA TAT ACT ATA TAA TCC TAA T & GCG GGG TTA GTC TTT TTA TTT AAC TTA A & 47 \\
\hline Satt285 & GCG ACA TAT TGC ATT AAA AAC ATA CTT & GCG GAC TAA TTC TAT TTT ACA CCA ACA AC & 47 \\
\hline Satt154 & AGA TAC TAA CAA GAG GCA TAA AAC T & AAA GAA ACG GAA CTA ATA CTA CAT T & 47 \\
\hline Satt002 & TGT GGG TAA AAT AGA TAA AAA T & TCA TTT TGA ATC GTT GAA & 47 \\
\hline Satt160 & TCC CAC ACA GTT TTC ATA TAA TAT A & CAT CAA AAG TTT ATA ACG TGT AGA T & 47 \\
\hline Satt565 & GCG CCC GGA ACT TGT AAT AAC CTA AT & GCG CTC TCT TAT GAT GTT CAT AAT AA & 56 \\
\hline Satt281 & AAG CTC CAC ATG CAG TTC AAA AC & TGC ATG GCA CGA GAA AGA AGT A & 47 \\
\hline Satt233 & AAG CAT ACT CGT CGT AAC & GCG GTG CAA AGA TAT TAG AAA & 47 \\
\hline Satt600 & GCG CAG GAA AAA AAA ACG CTT TTA TT & GCG CAA TCC ACT AGG TGT TAA T & 47 \\
\hline Satt434 & GCG TTC CGA TAT ACT ATA TAA TCC TAA T & GCG GGG TTA GTC TTT TTA TTT AAC TTA A & 47 \\
\hline Satt285 & GCG ACA TAT TGC ATT AAA AAC ATA CTT & GCG GAC TAA TTC TAT TTT ACA CCA ACA AC & 47 \\
\hline Satt142 & GGA CAA CAA CAG CGT TTT TAC & TTT GCC ACA AAG TTA ATT AAT GTC & 47 \\
\hline Satt545 & CAA TGC CAT TCC ATA TTT GTT & CAA TTG CCC TAG TTT TGA TAG & 56 \\
\hline Satt389 & GCG GCT GGT GTA TGG TGA AAT CA & GCG CCA AAA CCA AAA GTT ATA TC & 47 \\
\hline Satt431 & GCG TGG CAC CCT TGA TAA ATA A & GCG CAC GAA AGT TTT TCT GTA ACA & 47 \\
\hline Satt354 & GCG AAA ATG GAC ACC AAA AGT AGT TA & GCG ATG CAC ATC AAT TAG AAT ATA CAA & 47 \\
\hline Satt175 & GAC CTC GCT CTC TGT TTC TCA T & GGT GAC CAC CCC TAT TCC TTA T & 47 \\
\hline Satt194 & GGG CCC AAC TGA TAT TTA ATT GTA A & GCG CTT TGT GTT CCG ATT TTG AT & 47 \\
\hline
\end{tabular}

AT- Annealing temperature $\left({ }^{\circ} \mathrm{C}\right)$. 
age were subjected to analysis of variance (ANOVA) using SAS $^{\mathrm{m}}$ software package. Means were separated using Duncan Multiple Range Test (DMRT) at $5 \%$ level of significance. Principal component analysis was conducted using standardized data obtained from the accelerated aging characters to determine factors contributing to the variance. Components with Eigen values $>1.0$ were selected and factors with contributing characters values of $>6$ were considered relevant for principal component (Matus et al., 1999). Varieties were then clustered into groups using hierarchical clustering based on squared Euclidean distance using PAST v2.17 software (Hammer et al., 2001). Pearson's coefficients of correlations between germination loss and seedling vigor characters were determined using STAR 2.0.1 software.Genetic diversity, Polymorphic information content (PIC), gene diversity, heterozygosity, percentage polymorphism, inbreeding coef- ficient and average number of alleles were estimated using Power Marker v3.0 software (Liu and Muse, 2005). Cluster analysis based on Euclidean distance coefficient was obtained with the unweighted pair-group method based on the arithmetic mean (UPGMA) to generate the dendrogram using PAST v2.17 software (Hammer et al., 2001).

\section{RESULTS}

\subsection{RESPONSE OF SOYBEAN VARIETIES TO STOR- AGE STRESS}

The mean square values for germination loss ( $G$ loss), coefficient of velocity of germination (CVG), growth rate index (GRI), germination index (GI) and seedling vigor index

Table 3: Mean square of soybean viability and other seedling vigor characteristics

\begin{tabular}{lllllll}
\hline SOV & df & Gloss (\%) & GI & GRI & CVG & SVI \\
\hline Rep & 2 & 42.1 & 5.62 & 2.63 & 48.4 & 14.88 \\
Variety (V) & 14 & $1616.59^{* *}$ & $5831.03^{* *}$ & $662.92^{* *}$ & $233.18^{* *}$ & $219.15^{\star *}$ \\
Aging Period (A) & 4 & $28786.24^{* *}$ & $50587.99^{* *}$ & $4723.55^{\star *}$ & $633.39^{* *}$ & $3302.44^{* *}$ \\
V x A & 56 & $550.62^{\star *}$ & $1072.86^{* *}$ & $114.07^{\star *}$ & $75.35^{* *}$ & $47.64^{* *}$ \\
Error & 148 & 60.91 & 96.76 & 10.54 & 36.95 & 11.1 \\
\hline
\end{tabular}

${ }^{*},{ }^{*}$ significant at $\mathrm{p}=0.05$ and $\mathrm{p}=0.01$, respectively

SOV: Sources of variation; df: Degree of freedom; G loss: Germination loss; GI: Growth index; GRI: Growth rate index; CVG: Coefficient of velocity of germination; SVI: Seedling vigor index

Table 4: Mean values of germination loss and seedling vigor parameters of fifteen soybean varieties

\begin{tabular}{|c|c|c|c|c|c|}
\hline Variety & G. loss(\%) & GI & GRI & CVG & SVI \\
\hline TGX 1190-52F & $32.00^{\mathrm{ab}}$ & $85.73^{\mathrm{fg}}$ & $25.43^{\mathrm{g}}$ & $37.32^{\mathrm{bcd}}$ & $15.08^{\text {ef }}$ \\
\hline TGX 1989-48FN & $15.20^{\mathrm{g}}$ & $87.67^{\text {efg }}$ & $27.26^{\text {efg }}$ & $39.65^{\mathrm{abcd}}$ & $16.07^{\mathrm{def}}$ \\
\hline TGX 1989-49FN & $18.93^{\text {efg }}$ & $103.13^{c}$ & $31.48^{\mathrm{c}}$ & $41.27^{\mathrm{ab}}$ & $17.57^{\text {bcde }}$ \\
\hline TGX 1835-10E & $1.60^{\mathrm{h}}$ & $136.47^{\mathrm{a}}$ & $43.45^{\mathrm{a}}$ & $43.82^{\mathrm{a}}$ & $24.4^{\mathrm{a}}$ \\
\hline TGX 1990-46F & $22.4^{\mathrm{efd}}$ & $82.07^{\text {hg }}$ & $25.46^{\mathrm{g}}$ & $40.41^{\mathrm{abc}}$ & $14.99^{\mathrm{ef}}$ \\
\hline TGX 1990-95F & $32.80^{\mathrm{ab}}$ & $63.73^{\mathrm{i}}$ & $18.26^{\mathrm{i}}$ & $30.65^{\mathrm{e}}$ & $10.29^{\mathrm{g}}$ \\
\hline TGX 1987-19F & $29.60^{\mathrm{bc}}$ & $76.00^{\mathrm{h}}$ & $22.64^{\mathrm{h}}$ & $36.63^{\mathrm{bcd}}$ & $14.09^{f}$ \\
\hline TGX 1990-78F & $24.53^{\text {cde }}$ & $94.87^{\mathrm{de}}$ & $28.92^{\mathrm{def}}$ & $35.96^{\mathrm{cd}}$ & $17.83^{\mathrm{bcd}}$ \\
\hline TGX 1989-53FN & $26.67^{\mathrm{bcd}}$ & $88.53^{\text {efg }}$ & $26.68^{\mathrm{fg}}$ & $39.38^{\mathrm{abcd}}$ & $14.95^{\text {ef }}$ \\
\hline TGX 1989-75FN & $37.60^{\mathrm{a}}$ & $53.07^{j}$ & $14.84^{j}$ & $29.21^{\mathrm{e}}$ & $8.51^{\mathrm{g}}$ \\
\hline TGX 1990-114FN & $13.33^{\mathrm{g}}$ & $98.80^{\mathrm{cd}}$ & $29.31^{\text {cde }}$ & $37.84^{\mathrm{bcd}}$ & $19.69^{\mathrm{bc}}$ \\
\hline TGX 1990-110FN & $27.2^{\mathrm{bcd}}$ & $90.53^{\text {ef }}$ & $25.46^{\mathrm{g}}$ & $35.08^{\mathrm{d}}$ & $14.03^{\mathrm{f}}$ \\
\hline TGX 1440-1E & $16.53^{\mathrm{fg}}$ & $98.20^{\mathrm{cd}}$ & $29.92^{\text {cd }}$ & $39.79^{\mathrm{abcd}}$ & $17.09^{\text {cde }}$ \\
\hline TGX 1448-2E & $4.80^{\mathrm{h}}$ & $114.80^{\mathrm{b}}$ & $35.08^{b}$ & $40.24^{\mathrm{abc}}$ & $19.78^{\mathrm{b}}$ \\
\hline TGX 1740-1E & $13.33^{\mathrm{g}}$ & $89.73^{\text {efg }}$ & $27.88^{\operatorname{defg}}$ & $40.92^{\mathrm{abc}}$ & $16.14^{\mathrm{def}}$ \\
\hline
\end{tabular}

Mean followed by the same alphabets are not significantly different at $\mathrm{p}=0.05$

G loss: Germination loss; GI: Growth index; GRI: Growth rate index; CVG: Coefficient of velocity of germination; SVI: Seedling vigor index 
(SVI) of the fifteen soybean varieties as affected by accelerated aging and storage period are presented in Table 3. There were highly significant differences among soybean varieties in respect to their response to storage stress (temperature and pressure) as expressed by the germination loss and all the seedling vigor characteristics (Table 3).

There were significant differences among the soybean varieties with respect to their reactions to storage stress as measured by the germination loss and other seedling vigor characteristics at $p=0.05$ level of significance (Table 4). Germination loss among the varieties ranged from $1.6 \%$ to $37.6 \%$ (as a measure of the difference in germination \% between untreated seed and seed after 6 month of aging period). High germination loss (37.60\%, $32 \%, 32.8 \%$ ) was recorded in 'TGX1989-75FN', 'TGX1190-52F' and 'TGX1190-95F' respectively while low germination loss was observed in 'TGX1835-10E' (1.60) and 'TGX1448-2E' (4.80). There was no significant difference in the germination loss of 'TGX1989-48FN' (15.20), 'TGX 1989-49FN' (18.93), 'TGX1990-114FN' (13.33), 'TGX1440-1E-1E' (16.53) and 'TGX1740-1F' (13.33) (Table 4). Germination loss (G loss) decreased with increasing aging period, for instance the seeds had lost germination ability of about $63.73 \%$ as at 6 months of aging period. Other seedling vigor parameters (GI, GRI, CVG and SVI) decreased with increasing aging period (6 hours to 6 months) (Table 5).

\subsection{CLASSIFICATION OF SOYBEAN VARIETIES BASED ON RESPONSE OF THE SEEDS TO STORAGE STRESS}

The principal component analysis (PCA) based on response of the soybean varieties to storage stress revealed four component axes with Eigen values that were greater than 1.0. These accounted for $93.97 \%$ of the total variation. PC1 accounted for $76.16 \%$ of the variation with germination rate index and germination index being the major factor while the second principal component (PC2) was responsible for about $17.81 \%$ of the variation and was associated majorly with coefficient of velocity of germination and germination loss (Table 6). Soybean varieties were clustered into two major groups (A and B) based on hierarchical clustering using squared Euclidean distance. Cluster 1 contained two soybean varieties ((TGX1448-2E and TGX1835-10E). Cluster 2 was

Table 5: Effect of accelerated aging period on soybean seed viability

\begin{tabular}{llllll}
\hline Aging period & G loss $\%$ & GI & GRI & CVG & SVI \\
\hline 0 hour & $0.00^{\mathrm{d}}$ & $111.11^{\mathrm{ab}}$ & $32.23^{\mathrm{b}}$ & $33.98^{\mathrm{c}}$ & $17.97^{\mathrm{b}}$ \\
6 hours & $8.00^{\mathrm{c}}$ & $113.42^{\mathrm{a}}$ & $36.54^{\mathrm{a}}$ & $44.14^{\mathrm{a}}$ & $27.63^{\mathrm{a}}$ \\
12 hours & $10.22^{\mathrm{c}}$ & $108.27^{\mathrm{b}}$ & $32.47^{\mathrm{b}}$ & $37.08^{\mathrm{a}}$ & $12.22^{\mathrm{b}}$ \\
24 hours & $23.56^{\mathrm{b}}$ & $87.93^{\mathrm{c}}$ & $25.87^{\mathrm{c}}$ & $37.08^{\mathrm{b}}$ & $12.22^{\mathrm{c}}$ \\
6 months & $63.73^{\mathrm{a}}$ & $33.71^{\mathrm{d}}$ & $10.52^{\mathrm{d}}$ & $36.88^{\mathrm{b}}$ & $4.33^{\mathrm{d}}$ \\
\hline
\end{tabular}

Mean followed by the same alphabets are not significantly different at $\mathrm{p}=0.05$

G loss: Germination loss; CVG: Coefficient of velocity of germination; GRI: Growth rate index;

GI: Growth index; SVI: Seedling vigor index

Table 6: Characters with respect to its principal component (PC), Eigen values and variation based on response of the seed to storage stress

\begin{tabular}{llc}
\hline Characters & PC 1 & PC 2 \\
\hline Germination loss & -0.47 & 0.27 \\
Germination index & $0.50^{\star}$ & -0.13 \\
Germination rate index & $0.51^{\star}$ & -0.022 \\
Coefficient of velocity of germination & 0.22 & $0.96^{*}$ \\
Seedling vigor index & 0.47 & -0.01 \\
Eigen value & 3.81 & 0.89 \\
\% Variance & 76.16 & 17.81 \\
Cumulative & 76.16 & 93.97 \\
\hline
\end{tabular}

* component contributors 


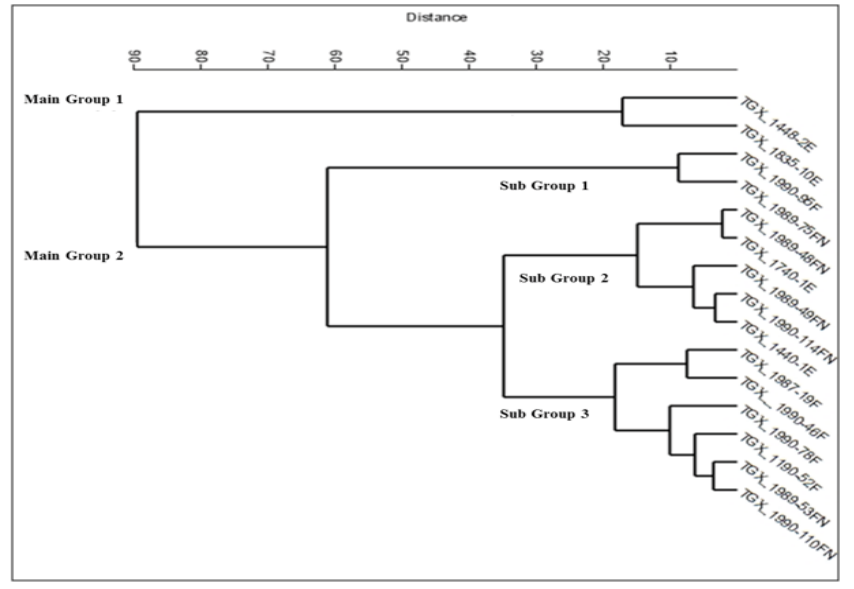

Figure 1: Dendrogram cluster grouping of 15 soybean varieties based on the response of the seed to storage stress

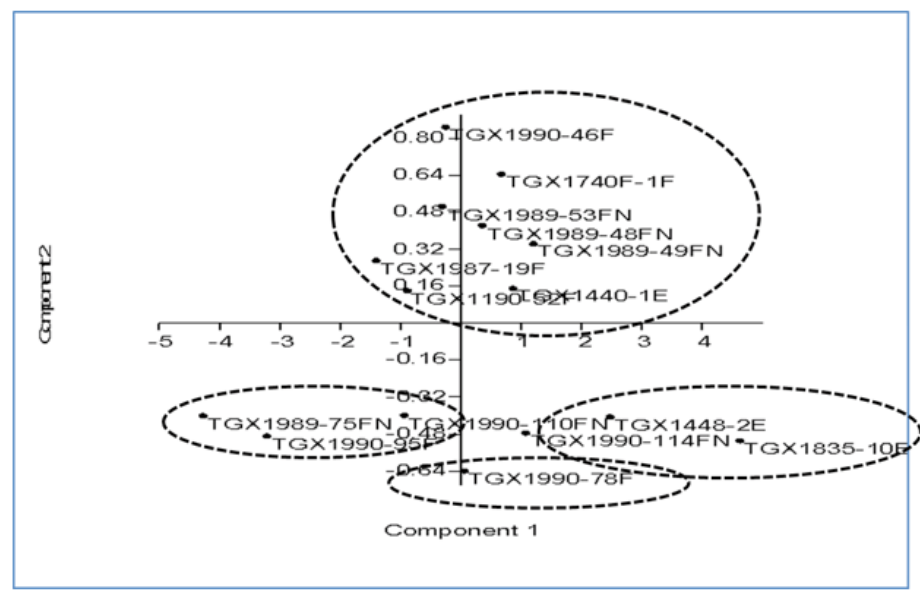

Figure 2: PCA scatter plot of soybean varieties evaluated based on the response of the seeds to storage stress on PC1 and PC2 axes

subdivided into three sub-groups. Sub-group 1 contained two varieties (TGX1990-95F and TGX1989-75EN), while sub-group 2 consisted of five varieties (TGX198949FN, TGX1740-1E, TGX1989-49FN, TGX1990-114FN and TGX1440-1E-1E) and sub-group 3 comprised six varieties (TGX1987-19F, TGX1990-46F, TGX1990-78F, TGX1190-52F, TGX1989-53FN and TGX1990-110FN) (Figure 1). The scatter plot of how the varieties are close to each other based on their response to storage stress shows that most of the varieties are similar to each other due to high germination loss after storage stress, hence they lied on the positive region of component 2. 'TGX 1448-2E', 'TGX 1990-114FN' and 'TGX 1835-10E' were similar to each other based on component 1 , which is dominated by high germination indices after storage stress. 'TGX-1990-78F' was partially separated from other varieties along the lower negative region component 2 (Figure2).

\subsection{CORRELATION BETWEEN PAIRS OF GER- MINATION LOSS AND SEEDLING VIGOR PARAM- ETERS AT EACH AGING PERIOD}

Correlation between pairs germination loss and seedling vigor parameters at each and across aging period showed that negative and significant association existed between pair of germination loss and seedling vigor parameters at 6 hours, 12 hours, 24 hours, 6 months and across aging period $\left(-0.96^{* *}\right.$ to $\left.-0.52^{*}\right)$ (Table 7$)$ Germination index (GI) correlated positively and significantly with germination growth index (GRI), coefficient of velocity of germination (CVG) and seedling vigor index (SVI), mostly at 12 hours, 24 hours, 6 months and across aging period $\left(0.61^{\star}\right.$ to $\left.0.99^{\star *}\right)$. Also, positive and significant relationship was recorded between pair of GRI with CVG and SVI, especially at 6 hours, 12 hours, 24 hours, 6 months and across aging period $\left(0.50^{\star}\right.$ to $\left.0.99^{\star *}\right)$. Similarly, CVG correlated significantly and positively with 
Table 7: Pearson correlation between pairs of aging period and germination loss and seedling vigour parameters

\begin{tabular}{|c|c|c|c|c|c|}
\hline & G loss $\%$ & GI & GRI & CVG & SVI \\
\hline & & & Before & & \\
\hline Gloss & - & - & - & - & - \\
\hline GI & & - & $0.93^{* *}$ & 0.43 & 0.39 \\
\hline GRI & & & - & $0.72^{\star \star}$ & 0.29 \\
\hline CVG & & & & - & -0.06 \\
\hline \multirow[t]{3}{*}{ SVI } & & & & & - \\
\hline & & 6 hours & & & \\
\hline & G loss & GI & GRI & CVG & SVI \\
\hline Gloss & - & $-0.52^{*}$ & $-0.88^{\star \star}$ & $-0.79^{\star *}$ & $-0.86^{* *}$ \\
\hline GI & & - & 0.47 & $0.61^{\star}$ & 0.38 \\
\hline GRI & & & - & $0.81^{\star \star}$ & $0.96^{\star *}$ \\
\hline CVG & & & & - & $0.73^{\star *}$ \\
\hline \multirow[t]{2}{*}{ SVI } & & & & & - \\
\hline & & 12 hours & & & \\
\hline Gloss & - & $-0.86^{\star \star}$ & $-0.85^{\star \star}$ & $-0.65^{\star \star}$ & $-0.81^{\star *}$ \\
\hline GI & & - & $0.98^{\star \star}$ & $0.72^{\star \star}$ & $0.92^{\star \star}$ \\
\hline GRI & & & - & $0.79^{\star \star}$ & $0.90^{\star \star}$ \\
\hline CVG & & & & - & $0.61^{\star}$ \\
\hline \multirow[t]{2}{*}{ SVI } & & & & & - \\
\hline & & 24 hours & & & \\
\hline Gloss & - & $-0.96^{\star \star}$ & $-0.95^{\star \star}$ & $-0.68^{\star \star}$ & $-0.92^{* *}$ \\
\hline GI & & - & $0.99^{\star \star}$ & $0.72^{\star \star}$ & $0.96^{\star \star}$ \\
\hline GRI & & & - & $0.72^{\star \star}$ & $0.96^{\star *}$ \\
\hline CVG & & & & - & $0.68^{*}$ \\
\hline \multirow[t]{3}{*}{ SVI } & & & & & - \\
\hline & & 6 months & & & \\
\hline & G loss & GI & GRI & CVG & SVI \\
\hline Gloss & - & $-0.85^{\star *}$ & $-0.96^{\star *}$ & -0.42 & $-0.96^{* *}$ \\
\hline GI & & - & $0.93^{* *}$ & $0.51^{\star}$ & $0.94^{* *}$ \\
\hline GRI & & & - & $0.50^{\star}$ & $0.99^{\star *}$ \\
\hline CVG & & & & - & $0.52^{*}$ \\
\hline \multirow[t]{2}{*}{ SVI } & & & & & - \\
\hline & & & Across & & \\
\hline Gloss & - & $-0.80^{\star *}$ & $-0.89^{\star \star}$ & $-0.88^{\star \star}$ & $-0.89^{* *}$ \\
\hline GI & & - & $0.85^{\star \star}$ & $0.81^{\star \star}$ & $0.82^{\star \star}$ \\
\hline GRI & & & - & $0.99^{\star *}$ & $0.97^{\star *}$ \\
\hline CVG & & & & - & $0.97^{\star *}$ \\
\hline SVI & & & & & - \\
\hline
\end{tabular}

*, ${ }^{* *}$ significant at $\mathrm{p}=0.05$ and $\mathrm{p}=0.01$, respectively

G loss: Germination loss; GI: Growth index; GRI: Growth rate index; CVG: Coefficient of velocity of germination; SVI: Seedling vigor index 
SVI at 6 hours, 12 hours, 24 hours, 6 months and across aging period $\left(0.52^{\star}\right.$ to $\left.0.97^{\star *}\right)$.

\subsection{CANDIDATE SSR MARKERS FOR DETECTION OF STORAGE STRESS TOLERANCE ALLELES IN SOYBEAN}

\subsubsection{Diversity studies}

Eighteen out of the nineteen SSR primers (94.74\%) used in this study were polymorphic and were able to detect SSR markers linked with alleles associated with storage stress tolerance among soybean varieties. The polymorphic markers produced a total of 72 alleles in the 15 soybean varieties. The alleles ranged from two to seven per locus, with an average of four alleles per primer. Primers (Satt 389 and Satt 600) had the highest number of alleles (seven), and the rests had two to five alleles. Principal information content (PIC) values for the SSR markers ranged from 0.28 (SATT 160) to 0.81 (SATT 389 ) with an average of 0.57 (Table 8).

Five SSR markers (Satt175, Satt 600, Satt 190, Satt 565 and Satt 160) clearly discriminated the soybean varieties into tolerant and susceptible varieties. Satt 600 had two alleles (Satt $600_{100}$ and Satt $600_{140}$ ) that linked with alleles in one of the tolerant variety (TGX1835-10E). Also, some other SSR primers like Satt 285 (Satt $285_{160}$ and Satt $285_{200}$ ) were associated with alleles responsible for susceptibility to storage stress.

\subsubsection{Genetic diversity of soybean varieties based on SSR molecular markers}

Genetic distance among the 15 soybean varieties ranged from 0.069 to 0.514 in (TGX1989-75FN, and TGX1990-114FN) to (TGX1989-49FN and TGX14401E) respectively with a mean value of 0.265 (Table 9 ). The dendrogram grouped the soybean varieties into two main groups (A and B). The first main cluster (A) comprised 3 varieties (TGX1440-1E, TGX1448 and TGX1740) while the second main cluster (B) comprised twelve varieties, which was sub-divided into four sub-groups sub-cluster 2 had only one variety (TGX 1835-10E). Sub-cluster 3 comprised four varieties (TGX1190-52F, TGX198948FN, TGX1989-49FN and TGX1990-46F). Sub-cluster 4 had three varieties (TGX1990-46F, TGX1987-19F, TGX1990-78F) and sub-cluster 5 consisted of four vari-

Table 8: Major alleles and polymorphism information content of eighteen SSR markers tested on fifteen soybean varieties

\begin{tabular}{|c|c|c|c|c|c|c|c|c|c|c|c|}
\hline S/No & Primer & MAF & $\mathrm{Na}$ & $\mathrm{Na}_{\text {ave }}$ & GD & $\mathrm{He}$ & MP & PP & $\% \mathrm{P}$ & PIC & I \\
\hline 1 & SATT423 & 0.40 & 4.00 & 2.07 & 0.66 & 0.80 & 0 & 4 & 100.00 & 0.59 & -0.18 \\
\hline 2 & SATT414 & 0.50 & 3.00 & 2.40 & 0.62 & 1.00 & 2 & 1 & 33.33 & 0.55 & -0.59 \\
\hline 3 & SATT434 & 0.54 & 3.00 & 2.47 & 0.57 & 0.93 & 0 & 3 & 100.00 & 0.49 & -0.59 \\
\hline 4 & SATT285 & 0.50 & 3.00 & 3.00 & 0.50 & 1.00 & 3 & 0 & 0.00 & 0.38 & -1.00 \\
\hline 5 & SATT154 & 0.38 & 3.00 & 1.47 & 0.66 & 0.69 & 0 & 3 & 100.00 & 0.59 & -0.01 \\
\hline 6 & SATT002 & 0.50 & 3.00 & 2.20 & 0.58 & 1.00 & 2 & 1 & 33.33 & 0.49 & -0.71 \\
\hline 7 & SATT160 & 0.83 & 4.00 & 1.07 & 0.30 & 0.25 & 0 & 4 & 100.00 & 0.28 & 0.20 \\
\hline 8 & SATT565 & 0.43 & 5.00 & 3.00 & 0.62 & 1.00 & 0 & 4 & 100.00 & 0.54 & -0.60 \\
\hline 9 & SATT281 & 0.37 & 6.00 & 4.33 & 0.76 & 1.00 & 0 & 6 & 100.00 & 0.72 & -0.29 \\
\hline 10 & SATT233 & 0.46 & 3.00 & 2.47 & 0.63 & 0.93 & 0 & 3 & 100.00 & 0.55 & -0.46 \\
\hline 11 & SATT285 & 0.50 & 3.00 & 2.60 & 0.53 & 0.93 & 0 & 3 & 100.00 & 0.42 & -0.72 \\
\hline 12 & SATT142 & 0.50 & 2.00 & 1.73 & 0.50 & 1.00 & 3 & 0 & 0.00 & 0.38 & -1.00 \\
\hline 13 & SATT545 & 0.50 & 3.00 & 2.47 & 0.62 & 1.00 & 2 & 1 & 33.33 & 0.55 & -0.58 \\
\hline 14 & SATT389 & 0.23 & 7.00 & 2.73 & 0.83 & 0.92 & 0 & 7 & 100.00 & 0.81 & -0.07 \\
\hline 15 & SATT431 & 0.46 & 5.00 & 2.00 & 0.67 & 1.00 & 0 & 5 & 100.00 & 2.00 & -0.46 \\
\hline 16 & SATT354 & 0.50 & 2.00 & 1.87 & 0.50 & 1.00 & 2 & 0 & 0.00 & 0.38 & -1.00 \\
\hline 17 & SAAT175 & 0.40 & 6.00 & 2.07 & 0.69 & 1.00 & 0 & 6 & 100.00 & 0.64 & -0.42 \\
\hline 18 & SATT600 & 0.33 & 7.00 & 1.80 & 0.76 & 0.67 & 0 & 7 & 100.00 & 0.73 & 0.16 \\
\hline
\end{tabular}

MAF: major allele frequency; Na: number of observed alleles; Naave: average number of alleles; polymorphic alleles; \% P: percentage polymorphism; PIC: polymorphic information content; I: inbreeding coefficient, He: heritability, MP: percentage monomorphism 
Table 9: Distance indices among fifteen soybean varieties based on DNA analysis

\begin{tabular}{|c|c|c|c|c|c|c|c|c|c|c|c|c|c|c|c|}
\hline & V1 & V2 & V3 & V4 & V5 & V6 & V7 & V8 & V9 & V10 & V11 & V12 & V13 & V14 & V15 \\
\hline V1 & - & 0.111 & 0.153 & 0.375 & 0.292 & 0.194 & 0.236 & 0.181 & 0.167 & 0.139 & 0.181 & 0.333 & 0.306 & 0.222 & 0.292 \\
\hline $\mathrm{V} 2$ & & - & 0.125 & 0.403 & 0.264 & 0.25 & 0.208 & 0.153 & 0.194 & 0.194 & 0.236 & 0.333 & 0.361 & 0.278 & 0.347 \\
\hline V3 & & & - & 0.361 & 0.278 & 0.236 & 0.194 & 0.167 & 0.125 & 0.208 & 0.222 & 0.236 & 0.347 & 0.292 & 0.278 \\
\hline V4 & & & & - & 0.389 & 0.403 & 0.389 & 0.389 & 0.403 & 0.375 & 0.361 & 0.375 & 0.514 & 0.347 & 0.472 \\
\hline V5 & & & & & - & 0.292 & 0.194 & 0.222 & 0.319 & 0.236 & 0.25 & 0.347 & 0.264 & 0.292 & 0.333 \\
\hline V6 & & & & & & - & 0.236 & 0.236 & 0.222 & 0.194 & 0.181 & 0.333 & 0.389 & 0.278 & 0.347 \\
\hline V7 & & & & & & & - & 0.167 & 0.208 & 0.181 & 0.194 & 0.236 & 0.236 & 0.264 & 0.25 \\
\hline V8 & & & & & & & & - & 0.208 & 0.125 & 0.194 & 0.292 & 0.375 & 0.292 & 0.389 \\
\hline V9 & & & & & & & & & - & 0.111 & 0.125 & 0.167 & 0.361 & 0.25 & 0.264 \\
\hline V10 & & & & & & & & & & - & 0.069 & 0.222 & 0.306 & 0.25 & 0.319 \\
\hline V11 & & & & & & & & & & & - & 0.181 & 0.292 & 0.264 & 0.306 \\
\hline V12 & & & & & & & & & & & & - & 0.333 & 0.361 & 0.347 \\
\hline V13 & & & & & & & & & & & & & - & 0.306 & 0.208 \\
\hline V14 & & & & & & & & & & & & & & - & 0.236 \\
\hline V15 & & & & & & & & & & & & & & & - \\
\hline
\end{tabular}

V1: TGX1990-52F; V2: TGX1989-48FN; V3: TGX1989-49FN; V4: TGX1835-10E; V5: TGX1990-46F; V6: TGX1990-46F; V7: TGX1987-19F; V8: TGX1990-78F; V9: TGX1989-53FN; V10: TGX1989-75FN; V11: TGX1990-114FN; V12: TGX1990-110FN; V13: TGX1440-1E; V14: TGX1448-2E; V15: TGX1740-1F

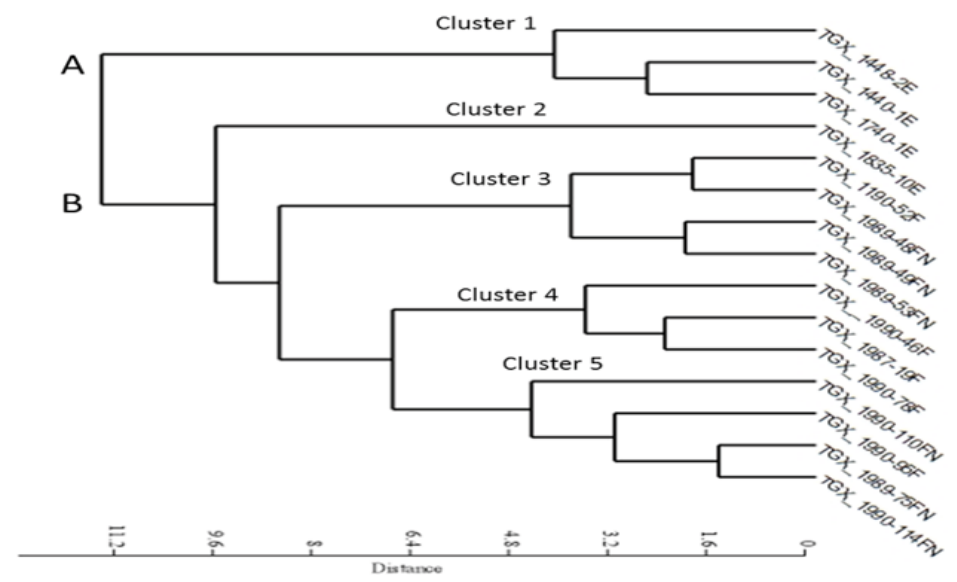

Figure 3: Dendrogram of 15 soybean varieties based on their genetic component identified using SSR markers

eties (TGX1990-110FN, TGX1990-95F, TGX1989-75FN, TGX1990-114FN) (Figure 3).

\section{DISCUSSION}

Seed storability is reported by Clerkx et al. (2004) to be a complex trait affected by environmental factors during seed formation, harvest and storage, and is usually controlled by several genes. The major storage stresses that seeds are exposed to are relative humidity and tem- perature. High germination loss and low seedling vigor parameters (GI, GRI, CVG and SVI) are indicators of low tolerance to storage stress imposed through accelerated aging and the ambient environment. Kehinde et al. (2013) found out that seed scientists have employed seeds viability and seedling vigor index to assess seed quality and the declined in these parameters have been associated with seed deterioration during storage. The significant variation observed in germination and other seedling vigor characteristics of the soybean varieties in 
this study can be attributed to the genetic makeup of the soybean varieties.

There were variations in the rate of deterioration of soybean varieties used in this study. This variation increased as the ageing duration increased. Similar result was reported by Jagadish et al. (2013) in the aging of forty soybean genotypes. This implies that seed deterioration of soybean is inevitable; however, varieties differed in their responses to aging factor that had been imposed on the seed due to storage stress. Also, it could be deduced that the significant variation observed in germination and other seedling vigor parameters under artificial aging treatments and ambient storage is due to different genetic makeup of the soybean varieties. Therefore, the diverse genetic constituent of the soybean varieties makes selection for storage stress tolerance possible. Adebisi et al. (2004) reported that seed quality and longevity performance are components of genetic make-up in soybean. Germination rate index and germination index accounted for the major factor to classify the varieties based on their tolerance to storage stress. This suggests that germination percentage is not the only factor that determines seed quality; therefore attention should be paid to these seedling vigor characters.

Simple correlation analysis has been considered adequate as a rough guide to the magnitude and direction of the relationships between two traits (Adebisi et al., 2010). High magnitude of coefficient of correlation (r) obtained among pairs of seedling vigor index at 6 hours, 12 hours, 24 hours, 6 months and across aging period, shows a strong association among the parameters and each parameter could be used to improve seedling vigor in cowpea.This corroborates with the findings of Brown and Caligari (2008) who reported that high and positive association between characters suggests that each of two parameters pairs could be controlled by closely linked genes, same or similar genes or by genes with pleiotropic effects on these parameters. However, negative and significant association was obtained between pair of germination loss and seedling vigor parameters at 6 hours, 12 hours, 24 hours, 6 months and across aging period. This implies that lower percentage germination loss leads to higher seedling growth parameters.

The clustering pattern of SSR markers agrees with the patterns obtained from accelerating aging imposed storage stress as regards grouping of susceptible soybean varieties to storage stress. Highly susceptible varieties (TGX 1990-95F and TGX 1989-75FN) were clustered together in all the trials, therefore this information confirms that these varieties will require improvement, if their cultivation will continue. SSR markers (Satt 600, Satt 285, Satt 175, Satt 190, Satt 565 and Satt 160) clearly distinguished the varieties into tolerant and susceptible varieties. These markers could have close linkage with good storability. SSR primers that were specifically associated with tolerance alleles (Satt 600) and susceptible alleles (Satt 285, Satt 281) identified were considered as good candidate markers for screening soybean germplasm for the identification of tolerance and susceptible genotypes in soybean breeding programmes. The results corroborates the work of Jagadish et al. (2013), Singh et al. (2008) and Dargahi et al. (2014) that identified same SSR markers to have linkage with storability traits in soybean. Hence, these markers are considered good candidate molecular markers for identifying alleles linked with tolerance or susceptibility to storage stress in soybean.

\section{CONCLUSION}

Soybean varieties differ in their response to storage stress. 'TGX1835-10E' and 'TGX1448-2E' were regarded as tolerant soybean varieties to storage stress as evident in the low germination loss recorded after subjecting them to accelerated ageing procedure. This is attributed to inherent genetic potentials to withstand storage stress. SSR markers Satt 565, Satt 175, Satt 281, Satt 600, Satt 160 and Satt 281 associated with storage stress in soybean seed. These candidate markers can be further studied on large soybean varieties to confirm their linkage with tolerant genes. This will be of immense uses to ascertaining their ability to soybean germplasm screening for seed storage tolerance breeding programs.

\section{REFERENCES}

Abbey, T. K. Essiah, J.W., Alhassan, A., Fometu, E., Ameyibor, K., and Wiredu, M. B. (2001). Integrated Science for Senior Secondary School. Unimax MacMillan Ltd. Ring Road South industrial Area Accra-North Ghana. Pp 177-178.

Adebisi, M. A., I. O. Daniel, I. O., M. O. Ajala, M. O. (2004a). Storage life of soybean seed after seed dressing. Journal of Tropical Agriculture, 42, 3-7.

Adebisi, M.A., Ajala, M.O., Ariyo. O.J. (2004b). Genetic studies on seed quality in sesame. Proceedings of the 29th Annual Conference of the Genetics Society of Nigeria. Pp. 209-212.

Adebisi, M.A., Okelola, F.S., Alake, C.O., Ayo-Vaughan, M.A., Ajala, M.O. (2010). Interrelationship between seed vigour traits and field performance in new rice for Africa (Nerica) genotypes (Oryza sativa L.). Journal of Agricultural Science and Environment, 10(2), 15-24.

Akande, S. R.,Olakojo, S. A., Ajayi, S. A., Owolade, O.F., Adetumbi, J. A., Adeniyan, O. N., Ogunbodede, B. A. (2012). Planting date effects on cowpea seed yield and quality at southern guinea Savanna of Nigeria. Seed Technology, 34, 79-88.

Badu-Apraku, B., Yallou, C.G., Obeng-Antwi, K., Alidu, H., 
Talabi, A.O., Annor, B., Oyekunle, M., Akaogu. I.C. and Aderounmu, M. (2017).Yield gains in extra-early maize cultivars of three breeding eras under multiple environments. Agronomy Journal, 109(2), 418. https://doi.org/10.2134/ agronj2016.10.0566

Baskin, C. C., Delouche, J.C. (1973). Accelerated aging techniques for predicting the relative storability of seed lots. Seed Science \& Technology, 14, 427-452.

Bhatia V. S. (1996). Seed longevity as affected by field weathering and its association with seed coat and pod characters in soybean. Seed Research, 24, 82-87.

Brown, J., and P. Caligari, (2008). An introductionto plant breeding. Blackwell Publishing Ltd, Oxford, UK. https://doi org/10.1002/9781118685228

Camara, Y. (2000). Profitability of cassava production system in West Africa: A comparative analysis (Cote. D' Ivore, Ghana and Nigeria), Ph. D. Thesis, Michigan State University, East.

Clerkx, E.J.M., El-Lithy, M.E., Vierling, E., Ruys, G.J., Blankestijin-De Vries, H., Groot S.P.C., Vreugdenhil, D., Koornnee, F.M. (2004). Analysis of natural allelic variation of Arabidopsis seed germination and seedlongevity traits between the accessions Landsbergerecta and Shakdara, using a new recombinant inbred line population. Plant Physiology, 135, 432-443. https://doi.org/10.1104/pp.103.036814

DargahiH.,Tanya, P., Srinives, P. (2014). Mapping of the genomic regions controlling seed storability in soybean (Glycine max (L.) Merill.). Journal of Genetics, 93, 365-370. https:// doi.org/10.1007/s12041-014-0381-0

Demir, I., Mavi, K. (2008). Controlled deterioration and accelerated aging tests to estimate the relative storagepotential of Cucurbit seed lots. Horticultural science, 43, 1544-1548. https://doi.org/10.21273/HORTSCI.43.5.1544

Dugje, I.Y., Omoigui, L.O., Ekeleme, F., Bandyopadhyay, R., Lava Kumar, P., Kamara, A.Y. (2009). Farmers' Guide to Soybean Production in Northern Nigeria. International Institute of Tropical Agriculture, Ibadan, Nigeria. $21 \mathrm{pp}$

Flajšman, M., Šantavec, I., Kolmanič, A., Košmelj, K., \& Kocjan-Ačko, D. (2019). Agronomic performance and stability of seed, protein and oil yields of seven soybean cultivars determined in field experiments in Slovenia. Genetika, 51(1), 31-46. https://doi.org/10.2298/GENSR1901031F

Hammer, D.A., Harper, T., Ryan, P.D. (2001). PAST: Palaeontological Statistics, version 2.17 software package for education and data analysis. Palaeontologia electronica, 4(1), 9 pp.

Hartman, G.L., West, E.D., Herman T. K. (2011). Crops that feed the World 2. Soybean worldwide production, use, and constraints caused by pathogens and pests. Food Security, 3, 5-17. https://doi.org/10.1007/s12571-010-0108-x

Hedley, C.L. ed. (2001). Carbohydrates in Grain Legume Seeds: Improving Nutritional Quality and Agronomic Characteristics. CABI Publishing: New York. https://doi. org/10.1079/9780851994673.0000

ISTA, (1996). Handbook of Vigor Test Methods ( ${ }^{\text {nd }}$ Edn), Inter- national Seed Testing Association, Zurich,Switzerland, pp 28-37.

Jagadish, H.A, Kumar, M.B, Talukdar, A., Lal1, S.K., Dadlani, M. (2013). Molecular characterization and identification of candidate markers for seed longevity in soybean [Glycine $\max (\mathrm{L}$.$) Merill]. Indian Journal of Genetics,73(1), 64-71.$ https://doi.org/10.5958/j.0019-5200.73.1.009

Kader, M.A. (2005). A comparison of seed germination calculation formulae and the associated interpretation of resulting data. Journal and Proceedings of the Royal Society of New South Wale, 138, 65-75.

Kehinde, T.O., Ajala, M.O., Daniel, I.O., Oyelakin, O.O. (2013). Physiological and genetic integrity of amaranth (Amaranthus spp.) seed during storage. International Journal of Plant Breeding and Seed Genetic, 7(1), 35-46. https://doi. org/10.3923/ijpbg.2013.35.46

Liu, K. and Muse, S.V. (2005). PowerMaker: integrated analysis environment for genetic marker data. Bioinformatics, 21(3), 2128-2129. https://doi.org/10.1093/bioinformatics/bti282

Matus, I., Gonzaléz, M.I., Pozo, A. (1999). An evaluation of phenotypic variation in a Chilean collection of garlic ( $\mathrm{Al}$ lium sativum L.) clones using multivariate analysis. Plant Genetic Resources Newsletter, 117, 31-36.

Nkang, A., Umho, E. O. (1996). Six month storability of five soybean cultivars as influenced by stage of harvest, storage temperature and relative humidity. Seed Science and Technolology, 25, 93-99.

Olisa, B.S., Ajayi, S.A., Akande, S.R. (2010). Physiological quality of seeds of promising African yam bean (Sphenomstylis stenocarpa (Hoechst. Ex A. Rich)Harms) and pigeon pea(Cajanus cajan (L.) Mill sp.) landraces. Research Journal of Seed Sciences, 3(2), 93-101. https://doi.org/10.3923/ rjss.2010.93.101

Scott, S.J., Jones, R.A., Williams, W.A. (1984). Review of data analysis methods for seed germination. Crop Science, 24, 1192-1 199. https://doi.org/10.2135/cropsci1984.0011183X 002400060043x

Singh, R. K., Raipuria, R. K., Bhatia, V. S., Rani, A., Pushpendra, T., Husain, S. M.,Satyavathi, C. T., Chauhan, G. S., Mohapatra, T. (2008). Identification of SSR markers associated with seed coat permeability and electrolyte leaching in soybean. Physiology and Molecular Biology of Plants, 14, 173-177. https://doi.org/10.1007/s12298-008-0016-0

Statistical Tool for Agricultural Research (STAR, Version: 2.0.1, 2013 - 2020). Rice Research Institute (IRRI). http://bbi.irri. org

Verma, D.P.S., Shoemaker, R.C. eds. (1996). Soybean Genetics, Molecular Biology and Biotechnology. CAB International: Wallingford.

Yuesheng, W., Jianbing, Q., Junyi, G., Guangyuang, H. (2006). Classification and characteristic of maturity groups of Chinese landraces of Soybean [Glycine max (L.) Merr.]. Genetic Resources and Crop Evolution, 53(4), 803-809. https:// doi.org/10.1007/s10722-004-5731-y 